\title{
EVALUATIONS OF THE MYSTICAL CONCEPTION OF RELIGION IN RUSSIAN SYNODAL ACADEMIC THEOLOGY AND TODAY'S CHALLENGES
}

\author{
VLADIMIR K. SHOKHIN
}

Russian Academy of Sciences

\begin{abstract}
The Russian academic theological tradition, scarcely known to the West, was the only milieu wherein the development of philosophy of religion in the pre-revolutionary Russia was under way. Philosophical investigation of the phenomenon of religion was being elaborated in the apologetic context, i.e. in critical analysis of non-theistic conceptions of the origin and essence of religion, and the figure of Friedrich Schleiermacher, with his reduction of religion firstly to cosmic feelings and later to the feeling of the ontological dependence, occupied an invariable place in this analysis. The paper deals with critical comments on Schleiermacher's Speeches on Religion and Christian Faith made by Victor Kudryavtsev-Platonov and his followers, which are being parsed in turn, as well as with historical links of the later Schleiermacher with phenomenology of religion and typological affinities of the earlier Schleiermacher with the theology of religious pluralism.
\end{abstract}

The philosophical constituent of the Russian spiritual academic tradition of the $19^{\text {th }}-20^{\text {th }}$ centuries, which falls in the concluding stage of the synodal period of Russian Church history, has not as yet received any deserved attention either abroad or even in the native historiography. The reasons in both cases are very similar. Foreign historians of Russian philosophy and even its not too numerous enthusiasts have not attached importance to it because nothing 'specifically Russian' is discerned in it. They haven't found there those manifestations of the so called 'mysterious Russian soul' which vent on a Westerner dealing with the feminine-romantic sophiology of Vladimir Solovyov and his numerous followers, with Pavel Florensky and Sergius Bulgakov at the head; the spiritual anarchism of Leo Tolstoy and his opponent Nikolai Feodorov; 
political anarchism of Alexander Herzen and Michael Bakunin; postslavophilemessianism (both nationalist and ecumenical at the same time) of Fyodor Dostoevsky and Nikolai Leontyev; the 'philosophy of freedom' and 'Russian idea' of Nikolai Berdyayev, etc. ${ }^{1}$ Even the most meticulous German historian of Russian philosophy has spared very few pages to Russian synodal academic philosophy, while mentioning sometimes that it proved to be not so much 'genuine' as rather 'engaged', 'employed' philosophy (eine Dienst-Philosophie). ${ }^{2}$ In Russia after the October revolution one of the best and painstaking historians of Russian philosophy, who strived just to be 'employed' by the new regime, also disavowed this philosophy as 'engaged', 'two-faced' and working on German copy-books. ${ }^{3}$ Surprisingly, the similar attitude to our academic philosophers predominated also in the Russian anticommunist emigrant milieu, where the best historian of Russian theology disavowed the very theological system wherein they were developing themselves as infected by a 'Western capture, ${ }^{4}$ and it was he who promoted the idea of 'the new patristic synthesis' (what its conception really did consist in was not, it seems, too clear even to its author) as an alternative to Western scholasticism. Even nowadays the most erudite Russian historians

${ }^{1}$ A representative example of what in Russian philosophy should be of interest for the Western audience is provided by the multi-volume Routledge Encyclopedia of Philosophy, which includes articles on 'Russian Materialism: "the 1860s"', 'Slavophilism', 'Russian Nihilism,' 'Nietzsche: Impact on Russian Thought,' 'Russian Liberalism, 'Russian Religious-Philosophical Renaissance, etc. There is only one article on Russian academic, i.e. professional, philosophy ('Russian Neo-Kantianism') and no article on the academic philosophy under discussion. The crucial article on Russian philosophy is prefaced with such a generalization as 'the principal contribution of Russian thinkers to the world culture has so far consisted not in systems, but in experiments in the theory and practice of human emancipation. Some of these led to the Russian Revolution, while others furnished remarkably accurate predictions of the nature of utopian power. Aileen Kelly, 'Russian Philosophy', The Routledge Encyclopedia of Philosophy, vol. 8 (London \& New York: Routledge, 1998), pp. 418-422 (p. 418). It is evident from this evaluation, very typical as it is, that 'Russian philosophy' and 'philosophy' are not regarded, in opposition to rationality, as species and genus, inasmuch as philosophy doesn't deal with the practice of human (political, etc.) emancipation, being (against Marx's illusions) only a theoretical undertaking of mankind.

${ }^{2}$ See, e.g., Wilhelm Goerdt, Russische Philosophie: Grundlagen (München: Alber, 1995).

${ }^{3}$ See, G. G. Spet, An Outline of the Development of Russian Philosophy, Part 1 (Moscow: ROSSPEN, 2008) (in Russian).

${ }^{4}$ See: Georges Florovsky, 'Ways of Russian Theology', Collected Works, vol. 5-6 (Belmont, MA: Nordland, 1979; Vaduz, Büchervertriebsanstalt, 1987). 
of the synodal theology virtually disregard the development of those disciplines where philosophy occupied crucial positions. ${ }^{5}$ Admittedly, we can observe some incipient interest in the synodal philosophers in Russia these days, but here we have only initial and not too resolute steps in this direction. ${ }^{6}$

It stands to reason that the aforementioned arguments and motives behind the disregard of the philosophy under discussion are quite inconsistent. As to the aforementioned features of 'genuine Russian philosophy', they are, certainly, of great interest for a student of culture, but hardly justify removal of interest in 'generally valid philosophy' in Russia. As to complaints against Russian academic philosophy because of its 'foreignness', they are, taking into account universal features of genuine philosophical, i.e. theoretical, activity, not much more persuasive as, e.g., virtual desires that also 'purely Russian' mathematics, biology or astrophysics should have emerged. Indeed, philosophy being intercultural by nature, and Russian academic philosophy being its species, incorporation of 'the foreign heritage' is not to be less natural here than, e.g., in logic or the theory of argumentation. Regarding complaints concerning the 'scholasticism' of our synodal philosophy, ${ }^{7}$ I'd object that such a format was universal in every 'professional philosophy', and, therefore, that these complaints can make sense only by admitting (such a viewpoint is rather popular) that a philosopher in Russia should be 'something more than a philosopher'. Without 'scholasticism' our academic philosophy could neither master, nor work out philosophical

${ }^{5}$ See, e.g., Nikolai Lisovoi, 'The Fundamental Overview: An Overview of the Main trends of Russian Theological Academic Science in the 19th - beginning of the 20th centuries', Theological Works (Bogoslovskiitrudi), col. 37 (Moscow: Publishing Council of the Russian Orthodox Church, 2002), pp. 5-128 (in Russian), where the primary focus is on dogmatics, but achievements in liturgical theology and church archaeology are also taken into account, and even comparative theology, i.e. almost everything with the exception of rational theology. None of Russian 'rational theologians' were honoured by any attention in a biased but interesting survey: N. K. Gavryushin, Russian Theology: Outlines and Portraits (Nizni Novgorod: Glagol, 2005) (in Russian; there are also later editions).

${ }^{6}$ One of more or less well-known publications is: Irina Tsvik, Russian Academic Theology in the 19th Century (Moscow: People's Friendship University of Russia, 2002) (in Russian). Here the philosophical constituents of all the four Russian spiritual academies are overviewed including academic attempts at the rational justification of theism and 'the academic epistemology' applied to knowledge of God. But the presentation of the subject-matter is more popular than rigorously academic.

${ }^{7}$ And just from there it was transplanted into secular university education. 
disciplines, philosophy of religion included, in systematic order, but would linger somewhere at the level of sophiology or 'public thought'. The only complaint deserving any attention could be a grudge against confessional biases, and we'll see that this complaint does have some validity: commitments sometimes did really interfere with objectivity. But we'll also see that they interfered without eliminating it, and, let's mention it right now, the adversaries of our academic philosophy were engaged much more. ${ }^{8}$

(1) Analysis of the mystical conception of religion which is of interest for us emerged in two formats of synodal theological activity. One of them corresponds to lectures in seminaries and academies on subjects very close to rational theology, the other to writings which had nothing to do with lecturing. In both cases estimations of the conception under discussion were being formed in a very important context. I mean elaborations of philosophy of religion, which sometimes was directly designated by this very name and sometimes by other terms, and here the academic philosophers have become pioneers in Russia. ${ }^{9}$ Academic professors themselves did not separate philosophy of religion as the philosophical investigation of the phenomenon of religion and its historical movement from the tasks of Christian apologetics, i.e. theology. But this fact by no means lowers the importance of what they were doing. It is well known that there are many problems with demarcation of philosophical disciplines even today. For example, 'philosophy of religion' in contemporary Anglo-American philosophy consists first and foremost in theistic metaphysics and only includes 'homeopathic doses' of reflection on religious experience and religiosity.

We'll confine ourselves to evaluations of the mystical conception of religion of Friedrich Ernst Daniel Schleiermacher (1768-1834). The named author made first-rate contributions to numerous philosophical

8 To mention only Gustav Spet (see above and note 3) who expressed unconcealed disgust both with the 'Byzantine backwardness' of our academic thought and its endeavours to study Western theological achievements, showing in this way the blending of general secularism with specific 'russophobia' at the same time.

9 'Lectures on Philosophy of Religion' were being delivered already in the Kiev Theological Academy by archpriest Ioann Skvortsov. Natalia Kutsentko, the investigator of his literary heritage, doesn't provide us with their dates, but alludes to some facts which suggest the 1830s as most probable. Natalia A. Kutsenko, 'Archpriest Ioann Skvortsov and the Kiev Academic-Theologian School', in Vladimir K. Shokhin (ed.), Philosophy of Religion: An Almanac 2006-2007 (Moscow: Nauka Publishers, 2007), pp. 397-398 (in Russian). 
fields (philosophy of religion, philosophical theology, epistemology, ethics, aesthetics, hermeneutics, history of Greek philosophy) and had a splendid career, which included work as a private tutor to the family of Friedrich Alexander the Earl in Dohna-Schlobitten, a position as chair of theology at the newly established Berlin University (in its foundation he took a prominent part), work as the philosophical secretary to the Prussian Academy of Sciences and one of the most distinguished preachers and organizers of reforms in the Prussian church, and activism in support of Protestant ecumenism in Germany. It was Viktor Dmitrievich Kudryavtsev-Platonov (1828-1891), an outstanding professor of Moscow Theological Academy, lecturer on metaphysics and history of ancient and modern philosophy, who offered determinant evaluations of Schleiermacher's mystical conception of religion. I mean his doctoral dissertation Religion, Its Essence and Origin (defended in 1873), which in the posthumous collection of his papers was included into the volume dealing with natural theology, where Schleiermacher's religiology was thoroughly analysed. ${ }^{10}$ The whole treaty consisted in two parts, that is criticisms of all nontheistic views of the essence and origin of religion (from the ancient atheistic ones up to the newest atheistic and nontheistic) and justification of theistic understanding of both 'objective' and 'subjective' origins of religion. A detailed analysis of Schleiermacher's understanding of religion ${ }^{11}$ is a part of the section dealing with deistic, pantheistic and rationalistic views. It was preceded by evaluations of the Kantian and Jacobean theories and followed by a section dealing with Hegel.

Kudryavtsev explored three Schleiermacherean compositions - On Religion: Speeches to Its Cultured Despisers (first edition 1799 and the fourth, noticeably revised, in 1831), The Dialectics (1811) and the dogmatic compendium Christian Faith in Outline (1821) ${ }^{12}$ along with

10 The term religiology as designating nonempirical religious studies was introduced by some German Catholic theologians (Religiologie) in the 1920s. Later Reinhard Pummer distinguished religiology from Religionswissenschaft as dealing with religion in the theological, philosophical, pastoral or ecumenical contexts. Cf.: Reinhard Pummer, 'Religionswissenschaft or Religiology?', Numen, vol. 19 (1972), 91-127 (p. 121). I willingly use this term here inasmuch as both Schleiermacher and Russian academic theologians dealt with religion and religions just from philosophical and, correspondingly, theological points of view.

${ }^{11}$ V. D. Kudryavtsev-Platonov, Collected Works, vol. II, fasc. 1 (Sergiev Posad, 1898), pp. 216-245 (in Russian).

${ }^{12}$ Kudryavtsev worked on the posthumous edition of this work (1861). 
a scarce secondary literature ${ }^{13}$ Kudryavtsev was sure there were important similarities between Schleiermacher's understanding of religion and that of Friedrich Jacobi (1743-1818): both philosophers located the essence and origin of religion neither in reason (as the deists and other rationalists did), nor in the moral self-consciousness of an individual (as Kant), but in 'the immediate feeling of the Divine', but while this concept remained 'unelaborated' with Jacobi and was treated by him as only one of a human's cognitive abilities, with Schleiermacher it has become 'systematized' to obtain the status of a 'self-contained principle'. Great merit is due to Schleiermacher's for focusing special attention on this feeling as 'an essentially important element in the affair of religion'. Kudryavtsev also acknowledged that his conception of religion was being gradually 'christianized', as one can judge by the gradual change in his identification of the very object of religious feeling. ${ }^{14}$ His criticism of the Schleiermacherean religiology was deployed in the context of the two origins of religion, i.e. the object and the subject of religious devotion.

As to 'the object of religion', its identification through the feeling of absolute dependence of a single person on the surrounding All-Unity bears 'a resolutely pantheistic character' which survives even in the revised editions of Speeches on Religion, when 'All-Unity' was substituted for 'God.' ${ }^{15}$ Indeed, as with Spinoza, so also with Schleiermacher, God is not the creator of the world but they are two mutually dependent principles, like natura naturans and natura naturata. ${ }^{16}$ 'The objective side of religion' with the earlier Schleiermacher was unworkable inasmuch as the universe cannot be such an object which could arouse specifically religious feelings in a human being. But even under the subsequent 'repair' of their object 'the whole objective contents of religion' was being deleted, its positive matter transformed into 'the mythology of subjective perceptions', and all knowledge about religion was demoted to 'psychological treatment on some feelings, and nothing more. ${ }^{17}$

'The subjective element' of the Schleiermacherean religion also raises numerous questions. In his early period Schleiermacher didn't make a distinction between the religious feeling and other senses as

${ }^{13}$ To wit the book: Karl Schwarz, Zur Geschichte der neuesten Theologie (Leipzig: Brockhaus, 1856). The author was a notorious representative of Liberal theology.

${ }_{14}$ V. D. Kudryavtsev-Platonov, op. cit., pp. 216, 224-225.

15 Ibid., pp. 221, 224.

${ }^{16}$ Ibid., pp. C. 243.

17 Ibid., pp. 227, 238, 236. 
they are. But also in the later versions of Speeches on Religion the German philosopher didn't realize that one can have 'the feeling of absolute dependency' (and here his religion is located) about anything: fate, an incident or the laws of nature worshipped also by the materialists. Baseless was also Schleiermacher's attempt to isolate the religious feeling from the whole domain of religious knowledge. Even in his definition of religion as the feeling of absolute dependency some element of knowledge is presupposed, but, to say more, according to common sense, religious feelings can be produced by religious ideas and not vice versa. Moreover, cognitive activity in religion, to say nothing of ethical, is incomparably higher and reveals the uniqueness of human nature much more than any feeling. In addition, Schleiermacher's views being accepted, one has to accept also that a human could be religious, nonreligious, or more or less religious not because of his free choice, but only because of 'the natural order of his nature, independent of him. ${ }^{18}$

As a result of Schleiermacher's psychologism and pantheism (Kudryavtsev was sure that the first involves the second), some views of religion in general and Christianity in particular were at hand, which are in reality incompatible with the latter. So, the importance of the creed and dogmas in religion is necessarily diminished, and they become only 'symbols of multiple modes of our heart'. Now, inasmuch as religious feelings, as Schleiermacher understands them, should be the same with all humans, all religions are to be equalized, and none of them should be regarded as higher or lower than any other. In spite of all his references to supernatural elements in Christianity, the whole array of thought of the German philosopher results in a negation of Revelation. While deism and other types of rationalism negate Revelation by means of radical separation of God and the world, here it is impossible because of their pantheistic confluence with each other. At last, Jesus Christ himself was for Schleiermacher only 'a religious virtuoso' because the Highest Being had the perfect and full habitat (Innewohnung) in him (and not because He is God Incarnated). ${ }^{19}$ The evaluation of Schleiermacher's religiology offered by Kudryavtsev-Platonov proved to be decisive for the whole Russian academic apologetics that followed.

In the Kazan Theological Academy, the course in Apologetics under the name of fundamental theology was introduced in the 1850s, the

18 Ibid., pp. 229-234.

19 Ibid., pp. 244. 
very title and general programme of it having been appropriated from Fundamentaltheologie, a sub-discipline recently established by German Catholics. The starting programme of the course presupposed four main sections. In the first of them the Christian view of the phenomenon of religion and its origin had been envisaged, in the context of the consistent criticisms of naturalistic, 'pantheistic' and other theories of religion (wherein it was interpreted as an epiphenomenon of other 'more basic' constituents of the human being); in the second a comparative overview of non-Christian religions (paganism, Judaism, Islam); the third should deal with Christianity as the only veritable and divinely inspired religion; while the last section dealt with Orthodoxy as the only veritable form of Christianity itself.$^{20}$

It was archimandrite Augustine (Gulyanitsky) who produced the first textbook on this discipline for seminaries, Handbook of Fundamental Theology (1876), and here formal parameters of the discipline were outlined very accurately. The author acknowledged that he had used not only the scheme established by archimandrite Chrisanphus (Retivtsev), the compiler of the programme itself, ${ }^{21}$ but drawn also from other sources freely. In reality, he begins with criticism just of those conceptions of religion which were scrutinized by Kudryavtsev-Platonov, although not without some modifications. As was the case with Kudryavtsev, the Schleiermacherean conception is installed between those of Kant (religion as morality) and Hegel (religion as philosophy), but his identification of religion as a feeling is brought together this time with those of Schiller and Goethe, and not of Jacobi. According to archimandrite Augustine, the aesthetic vision of religion was kindred to its understanding within the circle of German liberal theologians, called Neologeans, Schleiermacher being considered as their main spokesman. ${ }^{22}$ There were the Neologeans

${ }^{20}$ We have every reason to think that this very succession of issues had its origin in the first German university course entitled 'Fundamental Theologie'. I mean the threevolume magnum opus by Johannes Nepomukh Ehrlich, Handbook for Lecturing on the General Introduction into Theological Science and Theory of Religion and Revelation as the First Part of Fundamental Theology (1859) based on his lectures in Prague. The principal difference consisted in the fact that Ehrlich's course was concluded by an apology for Roman Catholicism (and, especially, its new dogmas) as 'the crown-jewel' of all religions while in Russian courses Orthodoxy occupied its place.

${ }^{21}$ As a published version of this course has not as yet come to us, we have reasons to suppose that archmandrite Augustine had access to its lithography or manuscripts.

${ }^{22}$ The term Neologeans, which designated an influential group of liberal Protestant theologians of the 18th century and whose earliest significant champions were Johann 
headed by him who insisted that religion is based 'on the feeling of absolute dependence on the Unlimited and striving towards it. ${ }^{23}$ The Russian theologian agrees with Schleiermacher's statement that 'the religious need manifests itself mainly in [the domain] of feeling, [that] of heart', but not with his belief that everything which we understand as religion can be exhausted by this sphere. Right knowledge both of religious truths and its commandments is also needed for the right religious activity, and it is by this reason that the domains of knowledge and action can by no means be neglected here. But also in the domain of the heart the contents of religion is not exhausted by the feeling of absolute dependency, in contrary, the feelings of freedom and 'filial boldness' in the face of God are by no means less essential. In addition, aesthetic feeling is not religious as such: to be religious one needs also to discern the divine presence behind the beauties of nature, the highest Beauty glimmering behind the splendid universe. That is why an artist can be insensitive to religion and a religious person to art. $^{24}$

The former Kazan professor archpriest Nikolai Rozdestvensky in his very detailed course for St Petersburg Theological Academy entitled as 'Christian Apologetics: a Course of Fundamental Theology' (1881/1882) also developed Kudryavtsev-Platonov's evaluations. He emphasized that Jacobi was the first to elevate feeling to the status of 'the specific instrument of religious life, but that this concept was not elaborated with him, ${ }^{25}$ and that only Schleiermacher managed to build a systematic theory of religion from this attitude. But Rozdestvensky expounds the train of Schleiermacher's thought more precisely than his predecessor: only a feeling can be related, according to the German philosopher, to

August Ernesti (1707-1781), Johannes Spalding (1714-1804) and Johannes Semler (1725-1804), was derived from 'a new teaching.' Already with Spalding the question was about the religion of individual feelings (opposed to the religion of the Church), which, contrary to the ethical norms, are unique with every person. As Spalding's disciple in Halle University, Schleiermacher was spiritually close to them, but he has not been included in their 'official list'. As to the Neologeans' religiology in general and in detail, see the corresponding chapter in the imperishable work: Konrad Feiereis, Die Umprägung der natürlichen Theologie in Religionsphilosophie: Ein Beitrag zur deutschen Geistesgeschichte des 18. Jahrhunderts (Leipzig: St. Benno, 1965), pp. 32-67.

${ }^{23}$ Augustine (Gulyanitsky), Handbook for Fundamental Theology (Vilna, 1876), p. 14 (in Russian).

${ }^{24}$ Ibid., p. 20.

${ }^{25}$ And, truly, he called this variously: now 'the feeling of faith', now 'the heart', now 'immediate contemplation'. 
the Infinite while activity and even thinking can linger only to finite objects. Like archmandrite Augustine, Rozdestvensky acknowledges that Schleiermacher was right in insisting on the centeredness of the feeling for the whole spiritual life (numerous passages from the Scripture are referred to confirming that it is the human heart that is most valuable for God), but Rozdestvensky joins Kudryavtsev in arguing that the domain of feeling does not constitute the highest level of this life and emphasizing that when religious strivings express themselves only as feelings they become indefinite and capricious, as is the case with the mystics. ${ }^{26}$ And here other results of exclusive 'sensationalism' in religious life are at hand, namely individualism, contempt for the Church and dogma itself (as the common faith of the whole Church) along with a sheer spiritual egocentrism. ${ }^{27}$ Again, Rozdestvensky develops archmandrite Augustine's argument that the feeling of absolute dependency is by no means the only and even most important among religious feelings, for even idolaters have the consciousness of freedom while negotiating with their idols about mutual profit. ${ }^{28} \mathrm{He}$ also stresses that the feeling of absolute dependency as the core of religion was not acknowledged even by Schleiermacher's followers, e.g., F.-A.-B. Nitzsch saw its essence more in a 'general unity of spiritual abilities' and August Twesten in the 'integrity' of spiritual life which cannot be reduced to the feeling of dependency. ${ }^{29}$

Fyodor Ornatsky, a chair of 'Introduction to theological sciences' at Kiev Theological Academy (that substituted here partly fundamental theology), devoted a whole book to the subject. His Schleiermacher's Teaching of Religion (1884) scrutinized in detail for the first time the evolution of Schleiermacher's philosophy of religion in Speeches on Religion (the first and following versions), Dialectics and Christian Faith in Outline. Nevertheless, in his estimation he also predominantly followed Kudryavtsev's pioneering work. To begin with, he differentiated between 'the object' and 'the subject' of the Schleiermacherean religion.

${ }^{26}$ N. P. Rozdestvensky, 'Christian Apologetics: The Course of Fundamental Theology Delivered to Students in 1881-2 Academic Year', the posthumous edition of St. Petersburg Theological Academy, prepared by Andrei Predtechensky, Pt. 1 (St. Petersburg, 1884), pp. 207, 212-214, 210 (in Russian).

${ }^{27}$ Ibid., p. 215.

${ }^{28}$ Ibid., pp. 216-217.

${ }^{29}$ Ibid., p. 218. August Twesten (1789-1876) was a professor of theology and repeatedly the president of Kiel and Berlin universities. Friedrich August Bertold Nitzsch (18321898) was a great theologian and had professorship up to the end of his career in Giessen. 
In the first case the initial Spinozism of the German philosopher was emphasized, which in spite of all his strivings for greater orthodoxy in his later texts had not allowed the Schleiermacherean God to become a more definite and definable principle (especially bearing in mind the philosopher's statement that a personal God would be unavoidably 'limited'). ${ }^{30}$ The Kievan professor follows Kudryavtsev also in his evaluation of the 'subjective side' of the religion of feelings as separated from both cognitive and moral activities, which leads to equalization of all religious traditions (by reason of the lack of criterion for their validity) and reduces 'religious knowledge' only to a 'reflexive description of religious feelings'. ${ }^{31}$ Again following Kudryavtsev, Ornatsky demonstrates that, in spite of the evolution of Schleiermacher's Christology, the founder of Christianity remains for the German philosopher nothing more than 'the archetype of piety', whose divinity is not beginningless, but only acquired by his cognition of God, that Jesus' miracles have only symbolical and not dogmatic significance, and that Revelation is in the framework of his semi-pantheism not so much 'the divine action' as 'the force of development, immanently inherent in humanity. ${ }^{32}$ Along with archimandrite Augustine and Rozdesvensky, Ornatsky criticizes Schleiermacher's reduction of the whole domain of religious feelings to the feeling of dependency, which, in reality, should be filled up with other ones, mostly by those of child-like and filial devotion. ${ }^{33}$

The distinctive contributions of Ornatsky's work, as compared to that of his predecessors, begin with his more enthusiastic acknowledgement of Schleiermacher's merits in detecting in the epoch of rationalism that religion was 'the essentially necessary and main constituent of the inner spiritual life of a human individual' having therefore the absolute value. Further, he more carefully traced Schleiermacher's progress from mixing intuitions and feelings to their demarcation. Lastly, he was more accurate than his predecessors in emphasizing the 'atomistic' nature of the religion of feelings: according to the German philosopher, there can be as many religions as there are religious individuals. ${ }^{34}$

\footnotetext{
${ }^{30}$ F. N. Ornatsky, Schleiermacher's Teaching of Religion (Kiev, 1884), pp. 176-178 (in Russian).

${ }^{31}$ Ibid., pp. 194-198.

${ }^{32}$ Ibid., pp. 218-219.

${ }^{33}$ Ibid., pp. 211-212.

${ }^{34}$ Ibid., pp. 189, 191, 193, 214-215.
} 
The latest more or less remarkable episode in the Russian evaluation of Schleiermacherean religiology is a chapter in Religion, its Essence and Origin: a Survey of Philosophical Hypotheses (1902-1904), a twovolume work of Kharkov University professor and archpriest Timotheus Butkevitch. It was not only in the title of his book that the author followed Kudryavtsev, whom he referred to willingly, but also in his estimations of well-known philosophers of religion. Nevertheless, he also made his own contribution. Still more than Ornatsky, Butkevitch underscores the scale and singularity of both Schleiermacher's personality and his theory of religion. He defends Schleiermacher vigorously against Hegel's haughty abuses, ${ }^{35}$ highlights his independence from Jacobi and partially draws him together with Jacob Fries (1773-1843) who also insisted that reason can be proficient only in the sphere of finite things, while beyond its limits it has to be guided by some 'for-feeling' (Ahndung). ${ }^{36}$ Now, more than all his precursors, Butkevitch pays attention to the earliest version of the Schleiermacherean religiology where the essence of religion was constituted by 'contemplation of the Infinite and awareness of the endlessness of the universe', and he doesn't see a real 'gap' (contrary to Ornatsky) between intuition and feeling in the first edition of Speeches on Religion. Nevertheless, this interpretation of religion was estimated by him as its reduction to aesthetic experience (similarities with Friedrich Schiller are drawn in this regard), and here he quotes not Russian authors but the famous Evangelical theologian Albrecht Ritschl. ${ }^{37}$ It is true that both sorts of experience are similar in many regards - first of all in the feeling of the sublime that engenders sensations of limitedness and smallness in the experiencer. Another similarity lies in the fact that while the beautiful is the object of aesthetic feelings, the object of religious feelings is the All-Perfect wherein beauty receives its highest accomplishment. ${ }^{38}$ Therefore it is quite natural that artists use religious subjects, but their very treatment of them demonstrates that religion and art are correlated with them as the means and end, not to mention that we have numerous examples of irreligious artists, and, therefore,

${ }^{35}$ It is well known that Hegel wrote, inter alia, that, in accordance with Schleiermacher's emphasis on the feeling of absolute dependency as the distinctive character of religiosity, a dog, absolutely dependent on its master, should be regarded as 'the best Christian'.

${ }^{36}$ Timotheus Butkevitch, Religion, Its Essence and Origin: A Survey of Philosophical Hypotheses, Book II (Kharkov, 1904), pp. 36-37, 22 (in Russian).

${ }^{37}$ Ibid., p. 21.

${ }^{38}$ Ibid., pp. 24-25. 
religious and aesthetical experiences differ. It is because of this mixing of different experiences that 'the chief contents of every empirical religion', i.e. God and Revelation, play the role of a secondary element in the religion offered by Schleiermacher. ${ }^{39}$

(2) Now it is the right time for the evaluation of the aforementioned evaluations themselves. And we'll start with what deserves some criticism.

To begin with, the identifications of the very milieu of the Schleiermacherean religiology, offered by Russian theologians, raise many questions. Neither Schiller and Goethe with their dissolving of religion into artistic feelings, nor even Jacobi (who did merely misunderstand Schleiermacher's conception of religion $)^{40}$ constituted the circle of thinkers mostly intimate to Schleiermacher. It is true that we come across the term Ahndung in the earliest version of Speeches on Religion, but this does not mean any special proximity to Fries. ${ }^{41}$ Archmandrite Augustine was much closer to the truth than KudryavtsevPlatonov by having mentioned the influence of the Neologeans: there are indubitable and clear traces of Semler's conception of 'a private religion' in the Schleiermacherean mystical individualism. ${ }^{42}$ But the main milieu

\footnotetext{
${ }^{39}$ Ibid., p. 13.

${ }^{40}$ According to Günter Meckenstock, one of the leading contemporary investigators of Schleiermacher, Jacobi, having looked through Speeches on Religion, detected in them nothing more than reproduction of the Fichtean idealism (opposed by him permanently). And Schleiermacher had all reasons to suspect that the venerable philosopher had not read it attentively, whereby he was seriously disappointed. See: Friedrich Schleiermacher, Über die Religion: Reden an die Gebildeten unter ihrerVerächtern (1799), ed. by Günter Meckenstock (New York: deGruyter, 1999), pp. 43-44.

${ }^{41}$ Ibid., p. 103, etc.

42 Semler already in his earlier work called even Baptism and Communion 'so called sacraments' and dogmas only 'various orders of a creed' whereby only 'the exterior churches' [italics are mine - V. Sh.] differ from each other and which have no relation to religion as it is, the latter being acquisition of 'the bliss and spiritual wellbeing of the Christians'. I. S. Semler, Ausführliche Erklärung über einige neue theologishe Aufgaben, Censuren und Klagen (Halle: C. H. Hemmerde, 1777), p. 36. This contrasting of religion with exterior church proved to be one of the most important feature of the Schleiermacherean religiology. In his later work Semler already explicitly distinguishers three kinds of religion, i.e. natural religion, church religion and private religion (Privatreligion). The main point of the latter is that endeavours of an individual's striving for 'moral well-being, inner self-development and bliss' cannot be regulated by any 'official prescriptions'. Idem., Ob der Geist der Widerchristus unserer Zeitalter auszeichne? In freimütigen Briefen zur Erleichterung der Privatreligion der Christen beantwortet (Halle: C. H. Hemmerde, 1784), pp. 76, 183, 211, 178.
} 
where this individualism blossomed was, certainly, the circle of Jena romanticism to which younger Schleiermacher did belong. The point is not only in enthusiastic estimations of Speeches on Religion by Friedrich Schlegel and Novalis, however important they are for the solution of 'the milieu issue. ${ }^{43}$ It was just the world-outlook of the Schlegels unto which the main initial Schleiermacherean 'religiological dispositions', mutually interconnected as they are, were fit perfectly, and one could count at least four of them. There are conceptions of a religious genius-virtuoso as the full legislator of the 'genuine religion' (cf. an artist genius as the law-giver of the artistic world); quite optional status of the traditional 'forms' of religion, constituted by a creed, hierarchy, scriptural texts etc. (cf. the same attitude to the traditional forms in literary writing); contraposition of intuition with rationality in religion; the principle of irony, consisting in the relativization of any forms wherein religious experience could be shaped. ${ }^{44}$

Now, all Russian academic theologians, even those manifesting objectivity in their acknowledgement of Schleiermacher's positive contribution into philosophy of religion (and Butkevitch proved the most unbiased among them), have not, nevertheless, estimated the very scale of the Schleiermacherean upheaval in the religiology of his times. Certainly, they were quite right while detecting reductionism there (see below). But reductionisms themselves can be different: it is one thing to reduce religion to the level of an auxiliary for one who desires to fulfil the moral law for the sake of the law itself (this Kantian view was predominant in the epoch of Schleiermacher), and another thing to reduce religiosity to the inner feelings wherein it is really located in 'the space of the inner man'. 'The principle of individuation' in itself didn't

${ }^{43}$ Friedrich Schlegel asserted in his 'Aphorisms', published in his journal Athanaeum, that nothing had been accomplished in his epoch in honour of Christianity comparable to Speeches on Religion (Number 112) and that one who feels the Highest Order in the depths of his soul but cannot express it in words, could find verbalization of his feelings in Speeches on Religion (Number 125). Also in his famous aphorism (Number 150) he recommended Schleiermacher as 'a new Spinoza'. Friedrich Schlegel, 'Ideen', Athenaeum: Eine Zeitschrift von August Wilhelm Schlegel und Friedrich Schlegel (1800), Bd. III, Stück 1, p. 32. Thereby Schlegel not only did his friend a bad turn from the political point of view, but overlooked that with Spinoza the world had been observed by 'the geometrical reason' while with Schleiermacher rather 'tasted' by aesthetical contemplation.

${ }^{44}$ See Vladimir K. Shokhin, Philosophy of Religion and Its Historical Shapes: From Antiquity to the End of the 18th Century (Moscow: Alpha-M, 2010), pp. 706, 743-744 (in Russian). 
deserve simple condemnation as well: a conscious religious person can and ought to find his (her) 'singular' path to God, founding him (her) self on his (her) and not another's 'contemplations', when, certainly, it is not opposed to the communal dimension of religion. In other words, one could mention that Schleiermacher was mistaken in denying the significance of 'cups' (at the early stage of his religiology) and by no means in asserting that of 'wine' in religion.

The criticism of 'blending' together of intuitions and feelings with Schleiermacher who had really seen them in unity (Anschauungen und Gefühle) ${ }_{{ }^{45}}$ was not, in my view, warranted either. Those feelings wherein the Schleiermacherean religion was located, i.e. those of unity with the Unlimited, then that of dependency on it, are not senses in the sensory sense and, being a 'vehicle' of the mystical experience, are in reality very similar to contemplations. Meanwhile, the intuition-cum-feeling of the absolute dependency was becoming paramount with Schleiermacher along with his gradual evolution from 'the cosmism' of the first edition of Speeches on Religion (where religion itself was defined as 'the feeling and taste for the Unlimited' $)^{46}$ to theism, but this movement remained underestimated by the Russian theologians. Certainly, they were right that the feeling of dependency cannot exhaust the whole gamut of religious feelings, and I'd mention that, e.g., the feeling of gratitude is still more basic for theistic religiosity. But Kudryavtsev-Platonov and Rozdestvensky were not quite fair by neglecting deep differences between the feeling of dependency manifested by a religious person and acknowledgement of his dependency on the laws of nature on the side of an atheistic scientist, and here were in some sympathy with Hegel's injustice (especially bearing in mind that Schleiermacher himself stated quite explicitly and more than once that Gefühl schlechthinniger Abhängigkeit (the feeling of absolute dependence) is the same as God realization).

But also in general the Russian commentators, guided by an a priori critical attitude towards Liberal Protestantism (whose leading spokesman Schleiermacher did really prove to be), practically ignored that

45 Friedrich Schleiermacher, Über die Religion: Reden an die Gebildeten unteri hrerVerächtern (1799), pp. 79, 144, etc. Compare his direct assertion: 'Anschauung ohne Gefühl ist nichts und kann weder den rechten Ursprung noch die rechte Kraft haben, Gefühl ohne Anschauung ist auch nichts: beide sind nur dann und deswegen etwas, wenn und weil sie ursprünglich Eins und ungetrennt sind.'

${ }^{46}$ Ibid., p. 80. 
substantial evolution which the Schleiermacherean religiology began to manifest is witnessed even earlier than in Christian Faith in Outline, namely in Christmas Eve: Dialogue on Incarnation (1806) read in Halle (whereafter Schleiermacher began to be persecuted by the ultra-liberal Hegelian theologian David Strauss). ${ }^{47}$ Kudryavtsev-Platonov was right that even in his Christian Faith in Outline Schleiermacher criticized the Church formulas concerning the theo-ontological status of Jesus Christ (firstly, the union of 'the two natures in one person') as well as the importance of the supernatural events for understanding his mission (firstly, resurrection, ascension and the second advent). ${ }^{48}$ But one could also mention that already in Short Outline of Theological Study (1811) in Berlin, justification of the superiority of Christianity over all other religions and 'churches' was featured as one of the main tasks of theology and the Church itself was acknowledged as a principle necessary for the development of human spirit $(\$ \$ 5,21,22) .{ }^{49}$ Therefore, one cannot speak about the simple reduction of religion to a feeling at this stage or religious individualism, which did possess the determinant importance at the initial stage of Schleiermacher's religiology.

Nevertheless, Russian academic theologians proved to be justified in many regards, to begin with Butkevitch's endeavour to detach the Schleiermacherean religiology according to the first version of Speeches on Religion from the later stages: here his neological-romantic understanding of religion was manifested in its primordeal blossom. Truthful also was his statement that the German philosopher considered religion and art to be close relatives - this is documented by his text quite well. ${ }^{50} \mathrm{But}$ not less justified was also the critique (initiated by Kudryavtsev-Platonov) of

47 See about that, e.g.: Hermann Fischer, 'Schleiermacher', Theologische Realenzyklopädie, Bd. XXX, ed. by Gerhard Müller (New York: Walter de Gruyter, 1999), pp. 143-89 (p. 160).

48 Friedrich Schleiermacher, Der Christliche Glaube nach den Grundsätzen der evangelischen Kirche im Zusammenhang dargestellt, bd. II (Berlin: G. Reimer, 1836), pp. 46-84, 84-93. It seems that Schleiermacher had nevertheless failed in overcoming his lingering undergraduate frustrations conditioned by his own inner opposition to the doctrines of Incarnation and Atonement, about which he wrote to his more orthodox father in 1787. See: B. A. Gerrish, A Prince of the Church: Schleiermacher and the Beginnings of Modern Theology (Philadelphia, PA: Fortress Press, 1984), p. 25.

${ }^{49}$ Friedrich Schleiermacher, Sämmtliche Werke, abt. I, bd.1 (Berlin: G. Reimer, 1843), pp. 6-7, 12-13.

50 See: Friedrich Schleiermacher, Über die Religion: Reden an die Gebildeten unter ihrerVerächtern (1799), p. 131, cf., p. 130. 
those conclusions which Schleiermacher inferred from his reduction of religion ('in the veridical sense') to individual 'intuitions and feelings' in the same version of Speeches on Religion.

To be sure, Kudryavtsev was not quite right insisting on the inferiority of the perceptive-cum-contemplative dimension of religion in comparison with others (see above), but he and his successors were justified in their verdict that Schleiermacher had artificially dissected the whole organism of religion into 'the authentic elements' and 'nonauthentic increments'. Given that his reductionism had advantages over Kant's (inasmuch as the latter reduced, in the final analysis, religion to a mere auxiliary of morality), Schleiermacher also selected from this whole what he preferred, and only his distribution of what is 'wheat' and what are 'tares' was different. This dissolution of what is undivided contradicts the constitutions of all developed religions which are formed not only out of 'intuitions and feelings' of their individual members (however important they are), but also from doctrinal, devotional and ethico-practical elements shared by whole communities. Thereby mystical 'intuitions and feelings' vary with members of different religions, e.g. a Muslim and Buddhist, not only in accordance with their personal inclinations and intuitions.

Russian theologians were also justified in their evaluation of the individualism of 'the primordial Schleiermacherean religion', which is not to be blended with the acknowledgement of individuality of religious subjects (see above), and even more than they fancied. The fact is that the German philosopher who undertook to make 'cultured despisers of religion' change their minds didn't noticed that he was one of them. While having begun his treatment with unmasking those who were still ready to tolerate somehow an individual religiosity but by no means religious communities, the earlier Schleiermacher himself seems to have despised everything constituting these communities, be it dogmas (cf. 'impious fetters of the creeds'), ${ }^{51}$ Scriptures, any church hierarchy, authority and the very division of a community into priesthood and laymen ${ }^{52}$ which is present in various shapes in all religions. He opposed 'one's own religion' of every religious atom (seine Religion) to a 'systematic' empirical

\footnotetext{
${ }^{51}$ Ibid., p. 155.

52 The younger Schleiermacher was sure that religious authority as it is provides for the spirit of sectarianism, which is much stronger with 'the systematic religion' (die systematische Religion) than with polytheists, and that the very division into priests and laymen enroots only in the weakness of religiosity in people. Ibid., pp. 145-146.
} 
religion: the latter is to be tolerated if and only if it will not stir mystically inspired 'narcissists' to coddle their individual spiritual sensations. Here Schleiermacher was a direct heir of the deists who built 'their religion' by contrasting 'inner' and 'outward' church to each other, and typological similarities with Kantian religion as 'an ethical community' (contrasted to an 'empirical church') are surely on hand. In general, his haughty idea that there are so many religions as individual religious intuitions and feelings (according to this logic, even a world religion should not differ in principle as a phenomenon from Mr. X's religion) gives an evidence that the slight, but very important dialectics of individuality and community in religion (without the first it degrades into ideology, without the second ceases to be religion) proved to be quite inaccessible for Schleiermacher at the early period.

The Russian theologians were not mistaken also in their persuasion that there is some connection between the understanding of the religious subject and object in Schleiermacher's philosophy of religion. Indeed, it was not correct to regard the classical rational pantheism of Spinoza to be Schleiermacher's world-outlook based on the conception of the 'intuitive-cum-sensing' religious subject. But if we identify the Schleiermacherean All-Unity as 'the universe of mystical experiences', all of them being equally veridical because of their mere existence, then we may speak about a kind of 'religious pantheism' without hesitation. Furthermore, some elements of more traditional Spinozism were also present in Schleiermacher's mind, when, e.g., he derided the teaching of personal immortality, opposing the idea of posthumous blending of souls to it. ${ }^{53}$ In that he didn't recognize a contradiction in his own thought, that is between this version of pantheism and his atomistic individualism which we have talked about in detail.

Again, Kudryavtsev-Platonov and his followers were right that in Schleiermacher's religion almost everything is reduced which has to do with Revelation. For him every spontaneous new vision of the nature (Anschauung des Universums) was already a revelation, and everyone was enabled to produce it from his own experience (and therefore

${ }^{53}$ He regarded the very hope for individual immortality a manifestation of human egocentrism striving to 'self-continuation'. He was sure that humans merely defend their selfhood from the authentic affection for the Universe, missing the chance to become bigger than they are and having no wish to 'merge in the Infinite while living among finite things'. Ibid., p. 114 et al. In the third edition of Speeches on Religion Schleiermacher changed the 'Universe' for 'God' but that has not changed the main idea. 
revelation has no transcendent origin $).{ }^{54}$

Last but not least, the Russian theologians' indication that the theoontological status of Jesus Christ in Schleiermacher's Christian Faith in Outline was 'modest' when compared with that in Orthodoxy, must be supplemented with such a specification that it was still incomparably 'humbler' in the first version of Speeches on Religion. Here the Saviour, along with God and angels, functions only as one of many useful support-images for mystical contemplation, being only 'another image' of fairies and sylphs. In contradiction to the Gospels, Schleiermacher also ascribes to Jesus indifference to 'his school' and his personal authority, while to 'the veridical Christianity' is ascribed an enthusiastic desire for the development of other 'new and stronger forms of religion' which would develop in the future. ${ }^{55}$ Here again Schleiermacher constructs his 'private Christianity' (cf. 'the private religion') in opposition to the historical tradition. For example, he ignores a strict statement that there is none other name under heaven given among men, whereby we must be saved (Acts 4:12). To this argument the younger Schleiermacher would have answered, most likely, that the spirit of a religion doesn't depend on 'the deadly letters' of the ancient documents but on the 'intuitions and feelings' of its adepts. ${ }^{56}$

(3) One of the earliest biographers of Schleiermacher (Otto Braun) did mention in his time that the latter had created not a school but a whole epoch in religious studies. I'd specify that he established not only a school (mentioned, by the way, also by Russian theologians - see above), but that he also inspired not one but many epochs in this field. And that he has done this in both of his mutually contradicting 'persons' (quite in the spirit of the romantic principle of wit and irony), both as an outstanding philosopher of religion and, what we have already alluded to, a refined

${ }^{54}$ Ibid., pp. 108-109. Here really one can detect links between religiology and the pan(en)theism of the German philosopher.

${ }^{55}$ Ibid., p. 193.

${ }^{56}$ In their criticisms Russian theologians were close to the first Protestant critics of Speeches on Religion. Noteworthy in this regard are the Heidelbergean professor of theology F.-G.-Ch. Schwarz, who perceived that Schleiermacher's 'religion of feelings' (Gefühlsreligion) leads to unlimited subjectivism, and his former patron F.-S.-H. Saak, who detected in Speeches on Religion a Spinozistic contempt for 'the religion of the simple-minded', and direct hypocrisy in Schleiermacher's discharging of a preacher's duties while writing them. Ibid., pp. 20-23, 43-45. In spite of Schleiermacher's energetic repudiation of the last abuses, it is not to be excluded that Saak's harsh but true verdict influenced Schleiermacher in his later movement towards a more orthodox Christianity. 
member of the class of 'religion's cultured despisers' (see above). In the first capacity he has made the becoming of the phenomenology of religion possible, inasmuch as his emphasis on 'intuitions and feelings' as the kernel of religiosity proved to become a necessary precondition of the theory of numinous feelings developed by Rudolph Otto and his successors. ${ }^{57}$ Some authoritative historians of the phenomenology of religion are sure that there are good reasons to consider the Schleiermacherean feeling of the absolute dependency as received not only in Otto's mysterium tremendum but also by his followers, e.g., in Friedrich Heiler's phenomenology of prayer and Gustav Mensching's conception of religion as the existential meeting with the sacred. But in this regard positive evaluations of Schleiermacher's achievements by Russian theologians have not passed, as we could make sure, ahead of their time. On the contrary, their criticisms of his philosophy of religion could be seen as in some degree demanded even for the present time, especially as applied to the early stage of Schleiermacher's religiology.

Unlike Schleiermacher, John Hick was not a genius, but a virtuoso in self-advertisement. As is well known, both he and his followers have presented his analysis of religious pluralism as a 'Copernican upheaval', in applying Kantian epistemology to religious studies, and so putting an end to 'Ptolemean Christocentrism' once and forever. Meanwhile, his terminologically mischievous 'The Real an sich' - which somehow lies as the basis of numerous 'the Reals for us', i.e. approximately equally transparent and limited lenses of the main religions (Hick was sure that he, as a 'commissioner of the Real-in-itself', had a gauge for measuring them) whereby the light of the Absolute which is transcending all of them (as the thing-in-itself in relation to appearances) and is manifested in their basic personal and impersonal symbols ${ }^{58}$ - was inspired not only by Kantian philosophy. And Hick by no means hastened to parade his other predecessors (not so advantageous for him as Kant). The very concept of the Real as the first principle providing the ontological foundation

${ }^{57}$ One can only mention that such a connoisseur of Otto as Robert Davidson asserted directly that the Schleiermacherean philosophy was a perpetual source of inspiration for Otto, and indeed became the point of departure for his main work The Holy (1917). Robert F. Davidson, Rudolph Otto's Interpretation of Religion (Princeton: Princeton University Press, 1947), p. 139.

58 This central Hickean doctrine with a Kantian 'warrant' is discussed in many of Hick's works. See especially John Hick, An Interpretation of Religion (London/New Haven: MacMillan/Yale University Press, 1989), pp. 233-251. 
for mystical experiences of the 'empirical [religious] traditions' was elaborated before him by Alan Watts, once one of the most famous American Buddhologists, in a book dealing with 'the mystical religion. ${ }^{59}$ The conception of the Absolute as being refracted in the different but equally valuable symbols of different religions was developed by the exceedingly popular German and American theologian Paul Tillich. The religiological path to such a concept of the Absolute, via relativization of such 'secondary elements' of historical religions as creeds, cults, scriptures and traditions, was elaborated by the Theosophists and Anthroposophists, as well as by Neo-Hinduists and missionaries of other Eastern religions who imposed on the Western audience the idea of the difference between Religion (with a capital letter) and 'empirical religions' (with a small letter). What remains after subtraction of all aforementioned 'secondary elements' of religions does correspond also with Hick to Religion, which is located in the universal revelation/ salvation/redemption process and designated by him as a passage from self-centredness to Reality-centredness.

In this differentiation of 'secondary' and 'primary' elements of religion he was congenial also to the earlier Schleiermacher, as we could make sure many times before, who, in turn, based himself on the Neologists (see above). But the similarities between these two philosophers of religion are by no means confined to this point. Hick's notion that the Real-an-sich ontologically undergirds the mystical experiences of various historical traditions (none of them having rights for 'special relations' with it) reminds one unmistakably of Schleiermacher's idea that the Universe can enliven any mode of 'intuition and feeling' sufficiently to form a new religion, which has equal rights with any old one. An essentially incoherent conception of refractions of the transcendent (by definition) Real in theistic and nontheistic basic symbols with the 'developed' Hick (crucial for all his religiology) ${ }^{60}$ again unmistakably reminds one of

59 No less than thirty years before the most well-known of Hick's publications he, having considered that his readers were already persuaded by him that 'Church religion is spiritually dead', offered as a substitute 'an interior, spiritual and mystical understanding of the old, traditional body of wisdom ... a conscious experience of being as one with Reality itself [italics are mine - V. Sh.]. Alan Watts, Behold the Spirit: A Study in the Necessity of Mystical Religion (New York: Random House/Pantheon Books, 1947), pp. $29,15$.

${ }^{60}$ The first of its flaws is that Real-an-sich, which by definition should be absolutely transcendent essence, is compelled for some reason to manifest itself in accordance with the basic symbols of quite empirical traditions, such as Adonai, The Celestial Father, 
the 'condescending' equalization of personal and impersonal aspects of the universal principle with the earlier Schleiermacher, as well as of the latter's persuasion that a religion without God can be by no means worse than one with Him. ${ }^{61}$ The Hickean religion wherein the loyalty of a member of any 'empirical community' to its dogmas and his (her) quite natural persuasion in the final verity of his (her) tradition are regarded as indications of spiritual immaturity and outdated exclusivism, excludes therefore missionary activity in the same degree as the Schleiermacherean 'cumulative religion' (die ganze Religion) wherein all 'physicists and mystics in religion, theists and pantheists elevated to the systematic outlook of the universe' could find their proper place, and endeavour for the conversion of anyone from one form of religion to another was characterized as 'a wild striving. ${ }^{62}$ In this context, it is also appropriate to note the similarity in views on the ontological status of the founder of Christianity, who, as the Russian theologians correctly stressed, with Schleiermacher was reduced from God Incarnate to the highest locus of

\begin{abstract}
Siva or the Brahman, Tao, Dharmakāya, etc. Another one is that, being above both divine persons and impersonal symbols as equidistant from them, the Real evidently manifests only the latter's features and only differs from the former ones, reminding one not so much of the Kantian Ding-an-sich as the Hindu scheme of trimurti, which, in its Vishnuite version, presupposes reduplication of Vishnu into Vishnu the Great One (which takes the role of the Absolute there) and Vishnu the small one, one of the former's 'empirical functions'. Again, Real-an-sich in its correlations with Real-for-us is much more familiar to the Advaitic distinction of Nirguna-Brahman and SagunaBrahman than to the Kantian critical ontology. One more flaw is that, when replying to the objection that his Real is powerless to help us decide which mutually contradictory doctrines of 'empirical religions' are true and which are false, Hick underscores again that these doctrines are located only in the domain of the Real-for-us and not the Realan-sich, but that seems similar to such a proposition that statements $2 \times 2=4,2 \times 2=$ 6 and $2 \times 2=8$ are also mutually exclusive only in the sphere of phenomena, while in reality, in the world of noumena $2 \times 2$ is above all such values. See: John Hick, Dialogues in the Philosophy of Religion (New York: Palgrave, 2001), pp. 191-193, where objections against the Real-an-sich and answers to them are presented concisely. As to some Indian analogies to Hickean 'ontology of religion', see: Vladimir K. Shokhin, 'On Some Features of Buddhist Missionary Work and Double Standards in Religious Studies', Studies in Interreligious Dialogue, vol. 15/2 (2005), pp. 133-154 (p. 141).

${ }^{61}$ Friedrich Schleiermacher, Über die Religion: Reden an die Gebildeten unter ihrer Verächtern (1799), pp. 111-112. It is well known that Hick started with rejection of 'Christo-centrism' in favour of 'Theocentrism', but then lent an ear to voices which had warned him that with 'Theo-centrism' the Buddhists, Taoists and non-theistic Hindus could be left outside his 'liberation/salvation' and in such a manner 'Reality-centrism' has emerged.
\end{abstract}

${ }^{62}$ Ibid., p. 139. 
acquisition of Divine knowledge and goodness in the human world and, with Hick, still further - to only one among many such loci. ${ }^{63}$

These similarities don't contradict some essential differences. Unlike Schleiermacher, Hick focused himself not so much on intuitions and feelings as on the 'undifferentiated soteriology'.64 In contrast to Schleiermacher, Hick cared not for individual religious 'intuitions and feelings' but for the world religions which he tried to catch in a dialogue basing himself on an opportunistic (however self-destructing it is) ideology of political correctness. Contrary to Schleiermacher who having begun his way with a 'mystical Spinozism', was steadily (though not coherently in everything) striving for more orthodox Christianity, Hick, having started with conversion into Presbyterianism, was steadily (and very consistently) coping with the task of removing Christianity from the contemporary world. These dissimilarities between the two philosophers don't disaffirm the presence of family resemblances between them, which don't rule out that one philosopher was in some degree inspired by another, and what is much more important, confirm the supposition that mystical reductionism is a very viable archetype in philosophy of religion.

${ }^{63}$ Just this idea was being substantiated, under the guise of standard Biblical criticism, in a special collection of papers edited by him and entitled The Myth of God Incarnate (1977). Hick offered side by side three arguments against the doctrine under discussion, namely, that it isn't contained in the primitive Christian faith for which Jesus' divine titles were nothing more than a pious metaphor, that to be God and man at the same time is to contradict logic and common sense, and that the doctrine puts Jesus from Nazareth into a privileged position over the founders of other creeds and, therefore, the doctrine of the Incarnation stands in the way of a dialogue between religions. John Hick (ed.), The Myth of God Incarnate (Philadelphia: Westminster, 1977), pp. 176, 178, 181. Having neither time nor space to discuss these arguments separately, I cannot but mention that together they are ranked in such illogical combination as could have taken place had someone, while proving that another has not levitated, argued that (1) the latter's ancestors didn't practice it; (2) this way of moving contradicts the laws of nature and (3) such a manner of movement could produce envy in the neighbours.

${ }^{64} \mathrm{~A}$ problem of this view is that it merges essentially incompatible patterns of summum bonum, inasmuch as 'salvation' presupposes just that theology and anthropology which cannot be harmonized with those backing up 'liberation'. Furthermore, it is not too easy to combine those ethical ideals, which the intentionally unscrupulous Hick fused in the unity of agapē/karunā: the first of them presupposes love of my neighbour while the second one a removal of both a neighbour and 'a distant one' via the practice of concentration and meditation aiming to demolish the very conceptions of ' $\mathrm{I}$ ' and 'mine' in one's consciousness. 